SECTION 5. Innovative technologies in science.

Azhibekova Zhanar Zhubandikovna candidate's (Ph.D) degree in Pedagogical sciences, associate professor Kazakh National Medical University named after S.Asfendiyarov, Kazakhstan azhibekzhanar70@mail.ru

Rakhimbaeva Gulbarshin Sabetovna senior teacher Kazakh National Medical University named after S.Asfendiyarov, Kazakhstan armanaru@mail.ru

Altekova Inzhu Serzhanovna senior teacher Kazakh National Medical University named after S.Asfendiyarov, Kazakhstan sagi.inju@mail.ru

\title{
INFORMATIONAL SYSTEMS IN PUBLIC SECTOR
}

Abstract: In this article studying of a course of informatics with use of interactive methods and acquaintance of students with the purposes and tasks of the program of formation of "The electronic government" in RK is considered.

Key words: informatics, method, innovation, Internet, Electronic government, site.

УДК 519.6;622.011.4;622.023

\section{ИНФОРМАЦИОНННЫЕ ТЕХНОЛОГИИ В УПРАВЛЕНИИ ГОСУДАРСТВОМ}

Аннотация: В данной статье рассматривается изучение курса информатики с использованием интерактивных методов и ознакомление студентов с целями и задачами программы формирования "Электронного правительства" в РК

Ключевые слова: информатика, метод, инновачия, Интернет, Электронного правительства, сайт.

Learning of informatics using interactive methods can help to intensify cognitive abilities of the students, to develop the ability of self-education and ability to work in the team, to develop and emerge communication skills and to enhance learning motivation. In classes on computer science it is very important to define which methods are required to teach topic. For generalization of previously learned materials we use several techniques, such as «brainstorming», «group discussion», «business game», teaching small groups, breaking down the lessons into smaller parts. Technique of small group discussion allow to each group member shares a group task, a mutual goal, and common resources (a shared text or problem). The characteristics of small group discussion are:

be solved step-by-step

Providing the students with detailed manuals showing how the problem should

$\checkmark \quad$ Students help each other learn

$\checkmark \quad$ Each group member has a responsibility to contribute to the group and do her/his "fair share"

$\checkmark \quad$ Each group concludes their work together by sharing the results of their work with others

$\checkmark \quad$ Clarifies value orientations of students 
Positive interdependence

and better influence to it;

Providing the students with opportunity to control own process od education

$\checkmark \quad$ The students are stimulated to actively participate

Method of small group discussion may applied for learning any topics of informatics such as repetition of knowledge, control of knowledge and getting new knowledge.

Thus, interactive techniques are allow to form active attitude to scientific - cognitive and educational - professional activity for students, which is based on position of life and professional self-determination of students.

The bottom line is that students are more able to learn together when you face each other in small circles. Students also support each other in learning when you make a commitment to solve problems jointly through discussion and shared explanations. They develop skills in leading, making decisions, building trust, and managing conflict. All of these skills are of value in today's workplace. Each group needs to regularly assess the effectiveness of its communication strategies and seek ways to improve group communication.

Learning of informatics using interactive methods can help to intensify cognitive abilities of the students, to develop the ability of self-education and ability to work in the team, to develop and emerge communication skills and to enhance learning motivation. Familiarize students with goals and objectives of the program of formation " Electronic government» in Kazakhstan, analysis of the current state of informatization in state agencies, and with main directions and mechanisms of implementation of the program. "Electronic government" was created for more effective, transparent and accessible work of government agencies.

Development of information and communication technology (ICT) now is a global trend of world development and scientific and technological revolution

Applying of ICT is crucial for improving the competitiveness of the economy, empowering its integration into the world economy, and for increasing public sector efficiency and to improve internal administration and management capabilities.

Information and communications technology (ICT) - stresses the role of unified communications of methods, processes, telecommunications, software and the integration storage, and audio-visual systems, which enable users to access, store, transmit, and manipulate information in the interests of its users.

Clearest positive impacts generated by ICT on public administration are in the areas of efficiency and productivity of government performance, and it could reduce the cost of bureaucratic procedures.

E-Government policies have largely conceived the use of ICTs as a further step in the re-organisation of the public sector along the basic principles of efficiency gains and costs savings that have driven many private sector ICT adoptions.

Directions:

$\begin{array}{ll}\checkmark & \text { interaction with citizens and businesses; } \\ \checkmark & \text { inner workings of state agencies; } \\ \checkmark & \text { interaction between a government. }\end{array}$

Economic effect of the introduction of ICT connected with:

the release of areas, previously spent on document storage; 
$\checkmark$ the reduced number of employees during the growth of the volume of work with documents;

$\checkmark$ the reduction of run-time business processes of government (related with in particular, time-saving operations on documents).

Great importance is the indirect effect of introduction, incudes:

$\checkmark \quad$ improve the quality of decisions;

$\checkmark \quad$ increase public confidence to government;

$\checkmark \quad$ reduction of indirect costs for the maintenance of public authorities.

"E-Government" refers to the use by government agencies of information technologies (such as Wide Area Networks, the Internet, and mobile computing) that have the ability to transform relations with citizens, businesses, and other arms of government. These technologies can serve a variety of different ends: better delivery of government services to citizens, improved interactions with business and industry, citizen empowerment through access to information, or more efficient government management. The resulting benefits can be less corruption, increased transparency, greater convenience, revenue growth, and/or cost reductions. The final stage of moving from traditional government to egovernment is defined by the existence of a single web portal, where you can find any government information.

All government services are possible only on-line and all administrative activities carried out by electronic devices, not based on paper use.

Introduction of "electronic government" - complex organizational, economic, technological and social process that demands considerable financial costs and administrative efforts.

Agency of Informatization \& Communication (AIC) takes in account experiences of egovernment in South Korea, Singapore, Italy, Germany and Estonia, after that the State program for the formation of "electronic government" in the Republic of Kazakhstan has developed with the help of international experts.

The State program for the formation of "electronic government" in the Republic of Kazakhstan for 2005-2007, was developed in accordance with the President's Message to the people of Kazakhstan from March 19, 2004, "For competitive Kazakhstan, competitive economy, competitive nation" taking into account the basic concept of "e-government" in the Republic of Kazakhstan, approved at a meeting of the Government of the Republic of Kazakhstan by the Protocol of June 8, 2004 N 9.

This program is based on the idea of achieving through the "electronic government" progressive informational Kazakhstan.

The main priorities for the creation of "electronic government" are that citizens have to get public access to the internet, development of levels of knowledge about information and communication technology as well as the modernization of public administration.

Development of infrastructure "electronic government" will be to implement in two related but functionally distinct circuits.

Internal circuit embraces relationships "Government to Governments " and includes information systems serving interagency administrative procedures. 
External circuits embraces relationships " Government to Citizens " and " Government to Businesses " and provides interaction between the state and citizens and organizations.

The program takes into account the main provisions of the State program of formation and development of the national information infrastructure of Kazakhstan, approved by the Decree of the President of the Republic of Kazakhstan dated March 16, 2001 number 573.

Purpose and Objectives of the Program

The program aims to provide citizens and organizations a quick and qualitative access to public services and improving the functioning of public authorities by the help of ICT.

To achieve this goal it is necessary to perform the following tasks:

1. creation of a regulatory legal and methodological framework allowing the state to citizens and organizations to function in the information society;

2. formation and development of e-government services;

3. provide to access to e-government organization works to eliminate information inequality and improve the level of education in ICT;

4. formation of the basic components of e-government infrastructure and optimization of information infrastructure of public authorities;

5. Protecting of information infrastructure for e-government.

E-government infrastructure are integrated state information resources in conjunction with the development of information services, providing citizens regulated by access to these resources.

\section{Literature:}

1. State program of formation of "The electronic government" in RK for 2005-2007 from 10.11.2004Г.

2. Andronova, A. Nikolaev the Electronic government in Europe and the world. O. Andronova of olga@ci.ru, A. Nikolaev, alnik@eureca.ru

3. Golobutsky A., O. Shevchuk "The electronic government"

4. Электронное правительство Республики Казахстан. [Электронный ресурс]. URL: www.e.gov.kz (дата обращения 18.02.2014).

5. Агентство по информатизации и связи. [Электронный ресурс]. URL: www.aic.gov.kz (дата обращения 18.02.2014).

6. Центр Компетенции по электронному правительству при Американской Торговой палате. [Электронный ресурс]. URL: www.e-govcompetence.ru (дата обращения 18.02.2014).

7. Фонд экономических исследований "Новая Экономика" [Электронный ресурс]. URL: www.neweco.ru, (дата обращения 18.02.2014).

8. "Электронная Россия" - федеральная программа [Электронный ресурс]. URL: www.e-rus.ru, (дата обращения 18.02.2014).

9. Департамент информации аппарата правительства РФ [Электронный ресурс]. URL: www.e-government.ru (дата обращения 18.02.2014).

10. Единый портал интерактивных государственных услуг [Электронный pecypc]. URL: www.e.gov.uz (дата обращения 18.02.2014). 